\title{
It's Not Just a Visit: Receiving Government Officials' Visits and Firm Performance in Ghina
}

\author{
Weiwen Li, ${ }^{1}$ Eric W. K. Tsang, ${ }^{2}$ Danglun Luo, ${ }^{1}$ and \\ Qianwei Ying ${ }^{3}$ \\ ${ }^{1}$ Sun Yat-sen University, China, ${ }^{2}$ University of Texas at Dallas, USA, and ${ }^{3}$ Sichuan University, \\ China
}

ABSTRACT Drawing upon signaling theory, we propose that a specific form of non-market action, receiving government officials' visits, reduces transaction costs between firms and their potential exchange partners and thus contributes to firms' competitive advantage in China. We also contend that severity of information asymmetry and availability of alternative ways of reducing transaction costs moderate the relationship between receiving government officials' visits and company financial performance in opposite directions. The former factor increases the ex ante value of receiving government officials' visits and strengthens its positive impact on financial performance, while the latter factor decreases the ex post value of receiving government officials' visits and reduces its positive impact. Our conceptual framework is supported by analyses that draw on a sample of listed manufacturing firms in China. Our study contributes to a more in-depth understanding of non-market actions in emerging economies, their contingencies, and their performance implications.

KEYWORDS firm performance, government officials' visits, non-market actions, signaling theory, sociopolitical legitimacy

\section{INTRODUGTION}

It is a great honor and privilege to host Mr. Fiang and the delegation at our headquarters. This high level visit once again reflects Fingli Green Energy's influence in the PV industry, and is also a positive sign showing valuable attention and support to renewable energy companies. We are inspired by the guests' interest in our industry as well as their compliments on our achievements. We look forward to leveraging our leading position in the industry to further contribute to a cleaner, greener world.

\section{Mao Liansheng, Chairman and CEO of Yingli Green Energy}

The above passage was excerpted from an announcement on the website of a solar energy company in China, Yingli Green Energy (NYSE: YGE). The announcement 
describes a visit to the company by a senior government delegation on March 5 and 6, 2010, headed by Jiang Zemin, former President of China. Increasingly, firms in emerging economies have employed non-market actions such as receiving government officials' visits (RGOV) to manage the institutional or societal context of economic competition (Choi, Jia, \& Lu, 2014; He \& Tian, 2008; He, Tian, \& Chen, 2007; Jia, 2014; Luo, 2006). Non-market actions are defined as the actions directed toward the political, social, or legal environment in order to secure permanent or temporary advantages (Hillman, Keim, \& Schuler, 2004; Shaffer, 1995; Sun, Mellahi, \& Wright, 2012).

Do non-market actions truly contribute to firm performance? Previous studies in this area seem to be inconclusive concerning the effect of non-market actions on firm performance. While some studies provided evidence that non-market actions, such as having a manager serve in a political capacity, are positively associated with firm performance (e.g., Hillman, Zardkoohi, \& Bierman, 1999), others found that nonmarket actions, such as lobbying, actually lead to inferior firm performance (e.g., Hadani \& Schuler, 2013). Indeed, even in emerging economies, where competition is greatly influenced by non-market forces, taking non-market actions, such as building strong government ties, does not necessarily result in positive firm value (Li \& Atuahene-Gima, 2001; Sun et al., 2012). Hence, different forms of nonmarket action might have distinct performance implications, and an examination of the effectiveness of non-market actions should focus on the characteristics of the actions (He et al., 2007; Shaffer, Quasney, \& Grimm, 2000). He and Tian (2008) noted that RGOV is one of the major forms of non-market actions used by firms in emerging economies such as China. Yet little is known about whether and how this form of non-market action is related to firm performance. The first objective of this study is, therefore, to examine how a specific non-market strategy (i.e., RGOV) would affect firm performance.

Prior research on non-market actions has emphasized the direct effect of such actions on firm performance. It has remained relatively silent regarding the boundary conditions of the effectiveness of non-market strategies. This is an important gap because the link between non-market actions and firm performance is not universal but could be context specific (Hadani \& Schuler, 2013; Sun, Mellahi, \& Thun, 2010). Indeed, a recent meta-analysis of the effectiveness of non-market actions revealed that the relationship between non-market actions and performance might be affected by contextual factors (Lux, Crook, \& Woehr, 2011). Further, studies on political connections, a specific form of non-market actions, suggested that the value of political connections is not universal, but could be contingent on both environmental and organizational factors (Li \& Zhang, 2007; Peng \& Luo, 2000; Sun et al., 2012). To address this deficiency of prior studies, our second objective is to investigate the boundary conditions of the effectiveness of RGOV.

This study chooses an emerging economy, China, as an empirical setting. Firms have been found to more actively take non-market actions in emerging economies where market-supporting institutions are less developed (Li \& Zhang, 2007). As 
the largest emerging economy in the world, China provides an interesting and rich setting to examine non-market actions.

\section{THEORETICAL BACKGROUND AND HYPOTHESES}

\section{Non-market Actions}

Prior studies on non-market actions can be divided into two main types, depending on the research context. The first type focuses mainly on non-market actions taken by firms from developed economies, in particular, the United States. These studies have examined a wide variety of such actions, including lobbying (Caldeira, Jojnacki, \& Wright, 2000), Political Action Committee (PAC) contributions (Burris, 2001), and testifying at government hearings (Hansen \& Mitchell, 2000). They mostly investigated the antecedents of non-market actions and found that issue specific, firm-level, industry-level, or societal-level factors are important drivers of such actions (Hillman et al., 2004). The focus of the second type of studies is on emerging economies, in particular, China. Most of these studies examined whether and how political connections might influence firm performance ( $\mathrm{Li} \& \mathrm{Zhang}$, 2007; Peng \& Luo, 2000; Sun et al., 2010).

Prior literature seems to assume that economic returns will result from nonmarket actions (Hillman et al., 1999). For example, Baron (1995: 47) defined non-market strategy as 'a concerted pattern of action taken in the nonmarket environment to create value by improving its overall performance'. In a similar vein, Oliver and Holzinger (2008: 496) referred to strategic political management, a key subset of non-market actions, as 'the set of strategic actions that firms plan and enact for the purpose of maximizing economic returns from the political environment'.

However, empirical evidence has been mixed. While Hillman et al. (1999), Marsh (1998), and Shaffer et al. (2000) demonstrated that non-market actions such as filing petitions to seek anti-dumping protection, having a manager serve in a political capacity, and testimony before Congress or administrative agencies indeed are associated with increased firm performance, Hadani and Schuler (2013) found that lobbying, PAC contributions, and hiring former public officials as directors are negatively associated with firm performance. Similarly, in the context of emerging economies, while managerial connections with government officials were found to be associated with higher firm performance (Peng \& Luo, 2000), organizational ties to political institutions might under certain circumstances have negative effects on firm value (Sun et al., 2010). It is hence possible that different forms of non-market actions might have distinct effects on firm performance, and that the mechanisms through which various forms of non-market strategies influence firm performance also differ. Treating all non-market actions as belonging to a homogeneous group might obscure the differences among these actions (He et al., 2007). A study of the effectiveness of non-market strategy thus should differentiate among non-market 
actions and focus on how a specific form of non-market actions would affect firm performance (Shaffer et al., 2000).

\section{RGOV as a Form of Non-market Actions}

Examining a specific form of non-market actions is important also because institutional differences across countries might drive firms to choose different forms of actions (Hillman et al., 2004). In particular, firms from developed economies such as the United States and those from emerging economies tend to use vastly different forms of non-market actions. For example, the former may rely on lobbying and PAC contributions as the major forms of actions (Lux et al., 2011). However, these two forms might be unviable or even illegal in emerging economies such as China. Instead, firms in emerging economies may take such actions as building informal relationships with government officials (Peng \& Luo, 2000) and participating in the parliament or other quasi-governmental organizations (Jia, 2014).

Employing a grounded theory approach, He and Tian (2008) identified RGOV as one major form of non-market actions taken by firms in China. Though they urged scholars to examine the performance implications of such non-market actions, to our knowledge no research to date has been done to empirically investigate the effectiveness of RGOV as a means of enhancing firm performance.

RGOV refers to the practice of companies hosting formal visits made by government officials, who may be of different levels of seniority. Visits by officials within their governmental jurisdictions have a long history in China (Hucker, 1951; Walker, 1947). In order to oversee the workings of local administrations, emperors in China relied upon personal visits to different regions (de Crespigny, 1981). In addition, the early Han dynasty (from 206 B.C. to 220 A.D.) instituted a system of touring inspectors, through which officers of the central government were sent from the capital to travel throughout the administrative regions known as commanderies in order to monitor the conduct of administrations, while commandery-level officers were sent to tour the counties and report to the commandery capital (Hucker, 1951). Though the system of touring inspectors underwent successive organizational development, it survived dynastic changes and internal disunity in China until the establishment of the People's Republic of China in 1949.

Government officials' visits to localities continued as an institutionalized practice of the Chinese Communist Party, though with changes reflecting the shift in government ideology. A strong example of the practice is the 1992 visit carried out by Deng Xiaoping, which was officially labeled 'a tour of inspection to the south', travelling from Beijing to Shanghai, and ending in Guangdong province. This tour was intended to signal to the world that the Chinese Communist Party was still committed to economic reforms even after the events of June 1989. Currently, RGOV is employed by firms as a non-market action in China, where government agencies still retain the right to allot strategic resources, approve projects, and intervene in business operations (Li \& Zhang, 2007). 


\section{Emerging Economy's Institutional Context}

Whether a form of non-market actions will lead to superior financial performance is dependent on the institutional context in which firms operate (Hadani \& Schuler, 2013; Hillman et al., 2004). Therefore, a discussion of the institutional environment of emerging economies will help us understand the mechanisms through which RGOV might have an impact on firm performance.

One common feature permeating emerging economies is the existence of severe information asymmetries among exchange partners resulting from the lack of market-supporting institutions (Luo \& Chung, 2013; Luo, 2003; Meyer, Estrin, Bhaumik, \& Peng, 2009). In the case of capital markets, market intermediaries such as financial analysts, mutual funds, investment bankers, venture capitalists, and financial news media are either absent or ineffective. Financial disclosure requirements are minimal and the rights of minority shareholders and creditors are often poorly protected (Khanna \& Palepu, 2000). Similar problems exist in product markets, where market intermediaries such as consumer-information organizations and government watchdog agencies are either absent or ineffective, and therefore there are few ways to corroborate the claims made by sellers $(\mathrm{Li}$, Chen, \& Shapiro, 2009). Labor, technology, and other markets are also prone to severe information asymmetries in emerging economies.

The presence of severe information asymmetries greatly increases transaction costs and has a negative impact on firm performance (Khanna \& Palepu, 1997; Meyer, 2001). Since the requisite information concerning a focal firm cannot be assembled reliably and cost-effectively, it is considerably more difficult and costly for emerging economy firms to acquire necessary resources and support (Meyer \& Peng, 2005).

\section{RGOV and Firm Performance}

Prior studies rely mainly on resource dependence theory to explain how non-market actions influence firm performance (Hillman et al., 2004; Lux et al., 2011). These studies argue that non-market actions could serve to reduce the dependence of firms on the government and accordingly contribute positively to firm financial performance (Hillman et al., 2004).

Drawing upon signaling theory, we propose that RGOV creates value for firms in emerging economies as it signals a firm's unobserved quality and therefore serves to reduce transaction costs among exchange partners. In emerging economies, due to severe information asymmetries resulted from weak institutional arrangements, an economically beneficial transaction might fail to be consummated if the transaction costs outweigh the potential benefits (Khanna \& Palepu, 1997; Meyer et al., 2009). In this situation, a firm capable of sending signals of unobserved quality will greatly alleviate its potential exchange partners' concern that the firm may have misrepresented its competencies (Rangan, 2000). The firm will need to spend 
much less time and effort on ex ante bargaining and contracting with its potential exchange partners (Dyer \& Chu, 2003). Hence as long as RGOV signals a firm's unobserved quality, it would allow the firm to economize on transaction costs and to consummate potentially favorable transactions.

In emerging economies, RGOV signals unobserved firm quality to potential exchange partners because of two interrelated social mechanisms: (1) relationships have reciprocal effects on the reputation of both the government officials and the firms receiving their visits, and (2) the evaluative capabilities of government officials are perceived to be strong.

The first mechanism posits that relationships have reciprocal influence on the reputation of actors. Government officials may risk their reputation by associating with firms of low quality. In our research context, firm quality is concerned with not only 'superior resources and capabilities as well as better market opportunities' (Ozmel, Reuer, \& Gulati, 2013: 853), as suggested by signaling studies of firm quality in developed economies, but also sociopolitical legitimacy, a critical success factor for emerging economy firms (Zhang \& Luo, 2013). Sociopolitical legitimacy is obtained when third parties regard a company as appropriate or right in terms of existing social norms and government policies (Aldrich \& Fiol, 1994; Suchman, 1995). Studies on IPO firms have suggested that investment bankers, senior executives, and board directors all have a concern over their reputation such that they are reluctant to be associated with companies that lack economic potential (Certo, 2003; Chen, Hambrick, \& Pollock, 2008; Cohen \& Dean, 2005; Higgins \& Gulati, 2003). Government officials in China have a similar concern, since their political career is highly dependent on their public image and reputation. A risk for government officials to visit low-quality firms is that once questionable products or corporate activities are revealed, there might be rumors that they exchanged favors with these firms. Hence, government officials have a strong incentive to avoid visiting lowquality firms. Through this mechanism, RGOV can raise third parties' estimates of the quality of the focal firm.

This reciprocal relationship mechanism also corresponds to the notion of signaling cost. A signal is effective when its cost associated with low-quality entities is much higher than their high-quality counterparts (Spence, 1973). In the case of RGOV, low-quality firms in emerging economies might lobby or even bribe government officials for their visits. However, the signaling cost (i.e., the cost of lobbying or bribing) will be very high and probably outweigh the potential benefits associated with the visit because government officials are highly reluctant to visit such firms.

As to the mechanism of quality assessment, potential exchange partners often trust the ability of government officials to discern firm quality (Stuart, 1998). This is especially the case in emerging economies such as China because governments typically keep a close eye on business organizations and use government agencies such as tax bureaus, statistical bureaus, and business supervision commissions to collect information on company operations (Qian \& Weingast, 1997). While 
tax bureaus and statistical bureaus collect detailed operational and performance information on companies, business supervision commissions (e.g., development and reform commissions, economic and trade commissions, and state-owned assets supervision and administration commissions) directly monitor the operation of businesses. Therefore government officials have a multitude of information sources, and are likely to have an in-depth understanding of the quality of a firm, which is not totally visible to the firm's potential exchange partners in emerging economies. Unlike the first mechanism, however, this one does not depend on the premise that the reputation of government officials is at stake in each of their visits.

Together, the above two social mechanisms suggest that RGOV signals a firm's unobserved quality. RGOV signals are observable because government officials' visits are typically reported in the headlines of national or local newspapers and are repeatedly reported by television news. Potential exchange partners are highly likely to be aware of government officials' visits, and may raise their assessment of the quality of the visited firms. Therefore RGOV helps reduce the information asymmetry and transaction costs between the focal firm and its exchange partners, and leads to better firm performance (Dyer \& Chu, 2003; Williamson, 1991). Hence, we propose:

\section{Hypothesis 1: RGOV will be positively related to firm financial performance.}

\section{The Contingent Values of RGOV}

In emerging economies, where weak institutional arrangements lead to information asymmetries, RGOV serves to reduce transaction costs between the focal firm and potential exchange partners, resulting in better firm performance. The relationship between RGOV and performance is expected to vary significantly with two contingency factors - the extent of information asymmetry and the availability of alternative ways of reducing transaction costs. The former factor determines the ex ante value of RGOV as a signal because in an environment where there is little information asymmetry between a firm and its potential exchange partners, it is not necessary for RGOV to signal unobserved firm quality in the first place. The latter factor, on the other hand, affects the ex post value of RGOV because if the focal firm has multiple means of reducing transaction costs, these means may replace RGOV in this respect and reduce its value. Within the constraint of data availability, we consider two sets of variables that are associated with these two factors: (1) firm age and regional market development, which affect the severity of information asymmetry, and (2) business group affiliation and company political connections, which determine whether companies have alternative means of reducing transaction costs.

Severity of information asymmetry. According to signaling theory, the value of signals tends to be more salient in contexts in which there is severe information asymmetry (Spence, 1973). Information asymmetry is especially salient for young companies, 
which face 'liability of newness' challenges (Higgins \& Gulati, 2006; Zott \& Huy, 2007). Since young companies lack a reliable track record, it is difficult for potential exchange partners to evaluate their quality. These potential exchange partners possess far less information than the company owners, and thus are reluctant to provide support to these companies (Zott \& Huy, 2007). In this circumstance, RGOV is particularly useful in reducing information asymmetry and attenuating potential exchange partners' concerns. Accordingly, we expect that RGOV is more valuable in signaling unobserved qualities for young companies than for old companies. Thus,

Hypothesis 2: The positive relationship between RGOV and firm financial performance will be stronger for young companies than for old companies.

Aside from firm age, information asymmetry between company owners and potential exchange partners is also affected by regional market development. In the process of development of emerging economies, large regional differences within a nation often exist (Meyer \& Nguyen, 2005). Although emerging economies have made great progress in recent years, the level of market development within large economies such as China and Russia is far from uniform (Li \& Qian, 2013). In general, potential exchange partners can obtain more reliable information on companies located in the relatively developed regions of a nation, where market intermediaries (such as investment banks, auditors, lawyers, and consultants) credibly communicate information between transaction parties (Chan, Makino, \& Isobe, 2010). Hence, potential exchange partners can readily obtain direct information about companies located in developed regions. They will accordingly rely less on indirect information such as the RGOV signal.

In contrast, information about companies located in less developed regions is not effectively communicated. Potential exchange partners find it difficult to obtain reliable information for assessing the operation and management of companies and thus are reluctant to provide cooperation and support (Khanna \& Palepu, 1997, 2000). In this case, RGOV is especially welcomed as a means for reducing information asymmetry between company owners and potential exchange partners. Hence, we hypothesize:

Hypothesis 3: The positive relationship between RGOV and firm financial performance will be stronger for companies located in less developed regions than for companies located in developed regions.

Alternative ways of reducing transaction costs. RGOV serves as an effective way of reducing transaction costs in emerging economies. This is especially so when alternative ways of reducing transaction costs are less accessible. Hence, companies without alternative mechanisms for reducing transaction costs should be more likely to benefit from RGOV. We examine two specific factors that affect the availability of alternative ways of reducing transaction costs - group affiliation and political connections. 
A business group can serve to reduce transaction costs by acting as an intermediary between individual affiliates within the group and imperfect markets and by replicating the functions provided by standalone intermediary institutions (Khanna \& Palepu, 2000). First, by putting the entire group's reputation at stake, a business group can credibly commit itself not to act opportunistically (Khanna \& Palepu, 1997). As a result, potential exchange partners such as suppliers are more willing to work with firms affiliated with business groups. Second, business group affiliates can get access to internal institutions. They can access capital, labor, and product markets from the business group, and exchange goods and services internally. Costs of such transactions are surely lower than those conducted with parties outside the group (Khana \& Palepu, 1997).

In contrast, non-group firms have very limited means of reducing transaction costs. They are in a greater need to assure potential exchange partners of their quality. Therefore, non-group firms may benefit more from RGOV in emerging economies. Accordingly, we propose the following hypothesis:

Hypothesis 4: The positive relationship between government officials' visits and firm financial performance will be stronger for firms without business group affiliations than for business group affiliates.

In addition to business group affiliation, political connections, an important type of managerial ties, can be another way of reducing transaction costs in emerging economies (Wang \& Qian, 2011). Firms with political connections can rely on such ties to anticipate policy changes, interpret regulations, enforce contracts, and settle negotiations (Peng \& Luo, 2000). Consequently potential exchange partners might have more confidence in doing businesses with such firms. On the other hand, companies without political connections lack this channel of assuring potential exchange partners. RGOV becomes particularly important for reducing transaction costs. Hence we propose:

Hypothesis 5: The positive relationship between government officials' visits and firm financial performance will be stronger for companies without political connections than for those with political connections.

\section{STUDY 1: AN EXPLORATORY GASE STUDY}

\section{Interviews and Company Visits}

Since there have been few studies of RGOV as a non-market action in China, the purpose of this case study is to gain a deeper understanding of the process through which RGOV occurs. Qualitative data were collected from three companies - two privately owned and one state-owned - in Guangdong province. In-depth interviews with CEOs and top managers from these companies were conducted in early 2010. All the companies had been visited by government officials before 2010. Each 
interview was tape-recorded and transcribed within 24 hours in order to reduce errors of recall. In addition, we followed the suggestions of Glaser and Strauss (1967), and triangulated the interview data with data collected from other sources, such as archival materials and direct observations during the company visits.

\section{Results of Qualitative Data Analysis}

The qualitative data reveal that RGOV often involves four steps. First, a firm that wants to be visited needs to seek help from a middleman in lobbying target government officials. Second, if the middleman, who usually has a close relationship with the officials, agrees to help, he or she will persuade them to visit the firm. Third, the officials evaluate the firm and decide whether or not to pay a visit. Finally, if the evaluation is positive, the firm will receive the visit and often publicizes it on its website afterwards. In this four-step process, the middleman plays a critical role in making the visit possible. The middleman's relationship with the government officials has to be close enough for generating lobbying opportunities. Moreover, it is important that the middleman has some knowledge of the schedule of the officials. Typically a visit to a firm is just one of the activities on their political agenda. If the middleman is familiar with the schedule, he or she can appropriately fit the visit into the schedule.

The CEO of a private firm that we interviewed said that he was fortunate to know the secretary of one senior government official very well. He once asked the secretary to arrange a visit to his firm by the official. The secretary subsequently arranged the visit when the official happened to tour the industrial park where the firm was located. Although the secretary had a very close relationship with the official, it still took a long time to arrange the visit mainly because the official had a tight schedule and was very stringent in selecting firms that he would visit. Another CEO whom we interviewed told a similar story. A middleman, who knew a government official well, first arranged a dinner for the CEO and the official. Subsequently the middleman lobbied the official to visit the CEO's firm. Almost one year after that dinner, the official paid a visit to the firm when he was leading a government delegation that visited the city where the firm was headquartered.

The above findings indicate that top management in China regards RGOV as an important non-market action, and that this non-market action is indeed costly, providing further support toward our argument that RGOV as a signal is costly in emerging economies.

\section{STUDY 2: A SEGONDARY DATA ANALYSIS}

\section{Sample Selection and Data Collection}

Our sample consisted of manufacturing companies listed on either the Shenzhen or Shanghai stock exchange from 2004 to 2007. We focused on manufacturing 
firms as they are more frequently visited by government officials than those from service sectors. Several data sources were used: the China Stock Market and Accounting Research (CSMAR) database, Wind Information (Wind Info), the National Economic Research Institute (NERI), and companies' websites. CSMAR and Wind Info are two of the leading financial data and financial software providers in Mainland China.

We used companies' websites as the major source of our data on RGOV. Company websites are a frequently used domain for understanding a company's interactions with government officials (He \& Tian, 2008; King, 1999). In order to communicate with external stakeholders, a public company typically has a webpage showing news concerning its recent events. This webpage is named as 'News and Events', 'News Room', or 'Press Release'. It is a common practice for companies in China to list a wide range of important events on this webpage, including information about RGOV.

One doctoral student checked the websites of the sampled companies, and collected data on the date a company received a government official's visit, the frequency a company received such visits in a particular year, the names of the government officials who paid visits to the sampled companies, and the level of those government officials. One author recollected those data on a random sample of 100 companies independently. The data collected by this author and those of the doctoral student were in total agreement. We confined our sample to companies that updated their events regularly, and excluded from our sample companies that had not updated their events for two consecutive months. This restriction resulted in a sample of 1565 firm-year observations. The selected companies represented about three quarters of the listed manufacturing companies in the Chinese stock market, and the two-sample t-tests showed that there were no significant differences in key firm characteristics (e.g., age, size, and financial performance) between companies in our sample and those that were excluded.

\section{Measures}

Firm performance. We used both accounting- and market-based measures of firm performance. The accounting-based measure was return on asset (ROA), which was calculated as net income over total assets. Since ROA as a ratio is a small number, regression coefficients might be too small to be stated in two decimal places. Hence, we multiplied the ratio by 100 and expressed it in percentage when ROA served as a dependent variable in a model (Table 4). The market-based measure was market-tobook ratio (MTB), which was calculated as a company's market capitalization divided by the company's total book value.

$R G O V$. The variable $R G O V$ is a dummy variable, indicating whether a firm received government officials' visits in a specific year. This variable was set to 1 if a company was visited by government officials at least once in a given year and 0 otherwise. To 
obtain the information on the visits, we checked the website of each of the sample companies during the observation period of 2004-2007. We used a firm-year unit of analysis, and measured this variable for each firm and in each year.

Moderating variables. For the first set of moderating variables, firm age was measured by the number of years since the firm's establishment. Market development was constructed from indices developed by Fan and Wang (2009) under the sponsorship of both NERI and its parent organization, the China Reform Foundation. The development score of the province in which a firm's headquarters was located formed the measure of market development for the firm. As to the second set, group affiliation was a dummy variable coded as 1 if a firm was affiliated with a business group, and 0 otherwise. Following Lu and Ma (2008) as well as Ma, Yao and Xi (2006), we coded a firm's affiliation with a business group on the basis of information from four annual editions of Large Corporations of China, a directory published by the National Statistics Bureau of China. Following the methods used in previous studies of political connections (Fan, Wong, \& Zhang, 2007; Li, Meng, \& Zhang, 2006), we used the CEO's affiliation with the government as the indicator of the firm's political connections. It was set to 1 if the CEO was a former official of the central government, the local government, an industry bureau, or the military; otherwise it was set to 0 .

Control variables. We controlled for other variables that might affect firm performance. First, we controlled for firm size, as larger companies might be able to attract more external support and therefore have better company performance (Stuart, Hoang, \& Hybels, 1999). Firm size was measured by the natural log of total assets. In addition, since the availability of unused debt capacity could have an impact on firm performance (Tan \& Peng, 2003), we controlled for company debt capacity in terms of current ratio, which was calculated as the ratio of current assets to current liability. Further, we controlled for firm reputation, because companies with good reputation were generally perceived as trustworthy (Roberts \& Dowling, 2002). Firm reputation was measured as a dummy variable equaling 1 if the company owned one or more well-known national brands, and 0 otherwise. In China, General Administration of Quality Supervision, Inspection and Quarantine (GAQSIQ) and State Administration for Industry and Commerce (SAIC) are the two major government bureaus in charge of brand evaluation. Every year GAQSIQ and SAIC select a batch of brands and give them the title of 'Chinese Top Brand' or 'Chinese Well-known Trademark'. As these two titles are highly recognized in China, we treated companies with at least one of these two titles as companies possessing well-known national brands.

Since firms with more technology resources might have competitive advantage (Song, Droge, Hanvanich, \& Calantone, 2005), we also controlled for technology resource. This variable was measured by a dummy variable equaling 1 if the company was recognized as 'Innovative Enterprise' by the Ministry of Science and 
Technology or as 'National High Tech Industrialization Demonstration Project' by the Development and Reform Commissions, and 0 otherwise.

Furthermore, companies with high advertising intensity might be able to attract more attention from stakeholders (Wang \& Qian, 2011). We controlled for advertising intensity, which was calculated as the ratio of selling, general, and administrative expenses (SG and A) to sales. We also controlled for state ownership, as state owned enterprises might have preferential access to government controlled resources $(\mathrm{Li}$ \& Zhang, 2007). State ownership was a dummy variable coded as 1 if the ultimate owner of a firm was the government or its agencies, and 0 if otherwise. The data on ultimate controller was from the CSMAR database. Finally, we included industry and year dummies to control for industry and year effects.

To establish that the relationships depicted in our hypotheses were causal rather than just correlational, we employed a one-year lagged design. All independent variables and control variables were lagged by one year.

\section{Estimation Method}

To study the impact of RGOV on company financial performance, it is important to account for the endogeneity of these visits. As noted, government officials tend to visit companies with characteristics that are seen as appropriate or right in view of existing social norms and government policies. These company characteristics could also influence financial performance through other means, such as being trusted by customers and suppliers. Hence, to the extent that we cannot identify and incorporate all those company characteristics into our empirical model and that the characteristics may influence both the chance of RGOV and financial performance, a simple ordinary least squares (OLS) regression model regressing financial performance on government officials' visits can lead to biased estimates (for a discussion, see Hamilton \& Nickerson, 2003; Shaver, 1998).

A switching regression model accounts for the possible omitted variable problem when the main independent variable is discrete in nature and the omitted variables influence both the discrete independent variable and the dependent variable (Masten, 1993). This method is widely used in strategy research (e.g., Hamilton \& Nickerson, 2003; Hasen, Kobeissi, \& Wang, 2011; Iyengar \& Zampelli, 2009; Leiblein, Reuer, \& Dalsace, 2002; Mayer \& Nickerson, 2005; Poppo \& Zenger, 1998; Shaver, 1998). To use the method, we first run a first-stage probit model to predict the likelihood that a firm would receive government officials' visits in a particular year. In this step, we calculate the inverse Mills ratio to recover the structure of the error variance.

All the moderating and control variables, lagged by one year, were included in the first-stage probit model to predict the likelihood that a firm would be visited by government officials in a particular year. We also included firm performance, which might partly reflect a firm's unobservable quality (Stuart et al., 1999). 
Table 1. Frequency of government officials' visits in each year

\begin{tabular}{lccc}
\hline \hline Year & $\begin{array}{c}\text { Number of } \\
\text { companies }\end{array}$ & $\begin{array}{c}\text { Number of companies receiving } \\
\text { government officials' visit }\end{array}$ & $\begin{array}{c}\text { Proportion of companies receiving } \\
\text { government officials' visit }\end{array}$ \\
\hline 2004 & 368 & 65 & $18 \%$ \\
2005 & 367 & 83 & $23 \%$ \\
2006 & 390 & 103 & $26 \%$ \\
2007 & 440 & 129 & $29 \%$ \\
Total & 1565 & 380 & $24 \%$ \\
\hline \hline
\end{tabular}

The second-stage model estimating performance splits the sample into companies that (a) have received government officials' visits and (b) have not received such visits. We estimate performance equations for these two subsamples by plugging in the appropriate inverse Mills ratios to correct for the self-selection bias.

In order to further address the potential endogeneity problem, we included in our first-stage probit model a dummy instrumental variable, capital city, which was coded as 1 if a firm's headquarters was located in the capital city of a province, and 0 otherwise. The capital city of a Chinese province tends to have a much bigger population and more companies than other cities within the same province. Firms located in capital cities are less likely to receive government officials' visits than those located in other cities because officials of capital cities are busier and the competition for the visits is also more intense. However, there is little theoretical reason to believe that capital cities have a direct influence on firm performance.

\section{RESULTS}

Table 1 shows the number of observations in the sample, and the number and proportion of companies that had received government officials' visits in each of the four years. Descriptive statistics and the correlation matrix are presented in Table 2. Table $2 \mathrm{a}$ includes the variables used in the first-stage probit model. As expected, firm size, advertising intensity, firm age, and political connection were significantly and positively correlated with the likelihood of RGOV. The descriptive statistics and correlation matrix for the key variables used in the second-stage analysis are presented in Table $2 \mathrm{~b}$.

\section{First-stage Probit Model Estimates}

Table 3 presents the results of the first-stage model, which was a probit regression of the likelihood of receiving government officials' visits. Model 1, the baseline model, included an intercept term and the main predictors of government officials' visits. Models 2 and 3 successively added the two pairs of moderating variables. 
Table 2a. Descriptive statistics and correlation matrix: switching regression first-stage variables ${ }^{\mathrm{a}}$

\begin{tabular}{|c|c|c|c|c|c|c|c|c|c|c|c|c|c|c|}
\hline Variables & Mean & S.D. & 1 & 2 & 3 & 4 & 5 & 6 & 7 & 8 & 9 & 10 & 11 & 12 \\
\hline 1. RGOV & 0.24 & 0.43 & & & & & & & & & & & & \\
\hline 2. Firm size & 20.96 & 0.96 & 0.14 & & & & & & & & & & & \\
\hline 3. Current ratio & 1.69 & 1.43 & 0.04 & -0.20 & & & & & & & & & & \\
\hline 4. Firm reputation & 0.17 & 0.38 & 0.05 & 0.07 & 0.04 & & & & & & & & & \\
\hline 5. Technology resource & 0.05 & 0.22 & 0.06 & 0.24 & -0.04 & 0.01 & & & & & & & & \\
\hline 6. Advertising intensity & 0.09 & 0.19 & 0.11 & -0.04 & 0.11 & 0.18 & -0.04 & & & & & & & \\
\hline 7. Capital city & 0.37 & 0.48 & -0.01 & 0.06 & 0.01 & -0.05 & 0.09 & 0.12 & & & & & & \\
\hline 8. Financial performance (ROA, in \%) & 3.02 & 8.40 & 0.12 & 0.04 & 0.20 & 0.02 & 0.03 & -0.01 & -0.01 & & & & & \\
\hline 9. State ownership & 0.59 & 0.49 & -0.02 & 0.26 & -0.02 & 0.08 & 0.09 & -0.12 & 0.15 & -0.15 & & & & \\
\hline 10. Firm age & 9.53 & 4.32 & 0.07 & 0.22 & -0.11 & 0.03 & 0.01 & 0.02 & 0.06 & -0.17 & 0.15 & & & \\
\hline 11. Market development & 0.75 & 0.43 & -0.07 & 0.04 & 0.04 & -0.01 & -0.02 & -0.13 & -0.14 & 0.04 & -0.04 & 0.05 & & \\
\hline 12. Group affiliation & 0.63 & 0.48 & 0.08 & 0.32 & -0.02 & 0.07 & 0.12 & -0.06 & 0.14 & 0.04 & 0.28 & 0.03 & 0.06 & \\
\hline 13. Political connection & 0.27 & 0.45 & 0.08 & 0.07 & -0.02 & -0.01 & 0.03 & 0.05 & -0.04 & 0.06 & -0.10 & -0.07 & 0.05 & -0.04 \\
\hline
\end{tabular}

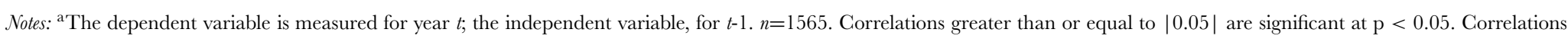
greater than or equal to $|0.07|$ are significant at $\mathrm{p}<0.01$. 
Table 2b. Descriptive statistics and correlation matrix: Switching regression second-stage variables ${ }^{\mathrm{a}}$

\begin{tabular}{|c|c|c|c|c|c|c|c|c|c|c|c|c|c|c|}
\hline Variables & Mean & S.D. & 1 & 2 & 3 & 4 & 5 & 6 & 7 & 8 & 9 & 10 & 11 & 12 \\
\hline 1. Financial performance (ROA, in \%) & 2.70 & 7.90 & & & & & & & & & & & & \\
\hline 2. Financial performance (MTB) & 1.60 & 1.02 & 0.16 & & & & & & & & & & & \\
\hline 3. Firm size & 21.10 & 0.95 & 0.06 & -0.26 & & & & & & & & & & \\
\hline 4. Current ratio & 1.71 & 1.47 & 0.25 & 0.12 & -0.23 & & & & & & & & & \\
\hline 5. Firm reputation & 0.17 & 0.38 & 0.06 & -0.01 & 0.05 & 0.02 & & & & & & & & \\
\hline 6. Technology resource & 0.05 & 0.22 & 0.03 & -0.03 & 0.24 & -0.05 & 0.01 & & & & & & & \\
\hline 7. Advertising intensity & 0.08 & 0.09 & 0.09 & 0.14 & -0.07 & 0.10 & 0.19 & -0.04 & & & & & & \\
\hline 8. State ownership & 0.60 & 0.49 & -0.09 & -0.12 & 0.19 & -0.08 & 0.06 & 0.08 & -0.13 & & & & & \\
\hline 9. Firm age & 9.53 & 4.32 & -0.16 & -0.06 & 0.17 & -0.16 & 0.03 & 0.01 & 0.01 & 0.18 & & & & \\
\hline 10. Market development & 0.75 & 0.43 & -0.01 & -0.10 & 0.06 & 0.04 & -0.01 & -0.02 & -0.12 & -0.02 & 0.05 & & & \\
\hline 11. Group affiliation & 0.63 & 0.48 & 0.08 & -0.08 & 0.31 & -0.04 & 0.08 & 0.12 & -0.08 & 0.29 & 0.03 & 0.06 & & \\
\hline 12. Political connection & 0.70 & 0.46 & 0.03 & -0.04 & 0.15 & -0.05 & -0.05 & 0.00 & -0.06 & 0.01 & 0.02 & 0.02 & 0.01 & \\
\hline 13. RGOV & 0.24 & 0.43 & 0.11 & 0.05 & 0.16 & 0.02 & 0.05 & 0.06 & 0.11 & -0.01 & 0.07 & -0.07 & 0.08 & 0.05 \\
\hline
\end{tabular}

Notes: ${ }^{a}$ The dependent variable is measured for year $t+1$; the independent variable, for year $t . n=1565$. Correlations greater than or equal to $|0.05|$ are significant at $\mathrm{p}<0.05$. Correlations greater than or equal to $|0.07|$ are significant at $\mathrm{p}<0.01$. 
Table 3. First-stage probit model of switching regression: RGOV at $\mathrm{t}$ on predictors at $\mathrm{t}-\mathrm{1}^{\mathrm{abc}}$

\begin{tabular}{|c|c|c|c|}
\hline variables & Model 1 & Model 2 & Model 3 \\
\hline Intercept & $\begin{array}{c}-6.48^{* *} \\
(0.96)\end{array}$ & $\begin{array}{c}-6.24^{* *} \\
(0.98)\end{array}$ & $\begin{array}{c}-5.33^{* *} \\
(1.00)\end{array}$ \\
\hline 1. Firm size & $\begin{array}{c}0.26^{* *} \\
(0.04)\end{array}$ & $\begin{array}{c}0.25^{* *} \\
(0.05)\end{array}$ & $\begin{array}{c}0.19^{* *} \\
(0.05)\end{array}$ \\
\hline 2. Current ratio & $\begin{array}{c}0.03 \\
(0.03)\end{array}$ & $\begin{array}{c}0.03 \\
(0.03)\end{array}$ & $\begin{array}{c}0.03 \\
(0.03)\end{array}$ \\
\hline 3. Firm reputation & $\begin{array}{c}0.09 \\
(0.10)\end{array}$ & $\begin{array}{c}0.08 \\
(0.10)\end{array}$ & $\begin{array}{c}0.07 \\
(0.10)\end{array}$ \\
\hline 4. Technology resource & $\begin{array}{c}0.20 \\
(0.17)\end{array}$ & $\begin{array}{c}0.21 \\
(0.17)\end{array}$ & $\begin{array}{c}0.19 \\
(0.17)\end{array}$ \\
\hline 5. Advertising intensity & $\begin{array}{c}0.65 \\
(0.52)\end{array}$ & $\begin{array}{c}0.50 \\
(0.53)\end{array}$ & $\begin{array}{c}0.51 \\
(0.53)\end{array}$ \\
\hline 6. Capital city & $\begin{array}{r}-0.19^{*} \\
(0.08)\end{array}$ & $\begin{array}{c}-0.22^{* *} \\
(0.08)\end{array}$ & $\begin{array}{c}-0.25^{* *} \\
(0.09)\end{array}$ \\
\hline 7. Firm performance (ROA) & $\begin{array}{c}0.03^{* *} \\
(0.01)\end{array}$ & $\begin{array}{c}3.08^{* *} \\
(0.70)\end{array}$ & $\begin{array}{c}2.87^{* *} \\
(0.70)\end{array}$ \\
\hline 8. State ownership & $\begin{array}{r}-0.10 \\
(0.09)\end{array}$ & $\begin{array}{r}-0.12 \\
(0.09)\end{array}$ & $\begin{array}{c}-0.18+ \\
(0.09)\end{array}$ \\
\hline 9. Firm age & & $\begin{array}{c}0.02^{*} \\
(0.01)\end{array}$ & $\begin{array}{c}0.02^{* *} \\
(0.01)\end{array}$ \\
\hline 10. Market development & & $\begin{array}{c}-0.26^{* *} \\
(0.09)\end{array}$ & $\begin{array}{c}-0.29^{* *} \\
(0.09)\end{array}$ \\
\hline 11. Group affiliation & & & $\begin{array}{c}0.33^{* *} \\
(0.09)\end{array}$ \\
\hline 12. Political connections & & & $\begin{array}{c}0.23^{* *} \\
(0.09)\end{array}$ \\
\hline Wald $\chi^{2}$ & $227.60^{* *}$ & $239.77^{* *}$ & $258.42^{* *}$ \\
\hline Pseudo $R^{2}$ & 0.13 & 0.14 & 0.15 \\
\hline
\end{tabular}

Notes: ${ }^{\mathrm{a}} n=1565$. Bracketed numbers are standardized errors.

$\mathrm{b}+\mathrm{p}<0.10{ }^{*} \mathrm{p}<0.05 ;^{* *} \mathrm{p}<0.01$; two-tailed tests.

${ }^{\mathrm{c}}$ All three models include nine industry dummy variables and three year dummy variables not reported here.

The validity of our instrumental variable, capital city, hinges upon the satisfaction of the relevance condition and the exclusion restriction. The relevance condition is satisfied as indicated by the highly significant association between capital city and RGOV $(\mathrm{p}<0.01)$ in Model 3 of Table 3. The exclusion restriction is also satisfied capital city did not significantly affect firm performance, as indicated by a separate analysis not presented here.

\section{Second-stage Financial Performance Estimates}

Table 4 presents the results of second-stage performance models of switching regression using inverse Mills ratios from the first-stage profit models in Table 3, which accounted for selection bias. Models 1 and 3 show the performance models for companies that received government officials' visits, whereas Models 2 and 4 show the results for those that did not. The inverse Mills ratio was added to correct 
Table 4. Second-stage performance models of switching regression: Financial performance at $\mathrm{t}+1$ on predictors at $\mathrm{t}^{\mathrm{abc}}$

\begin{tabular}{|c|c|c|c|c|}
\hline \multirow[b]{2}{*}{$\begin{array}{l}\text { Independent } \\
\text { Variables }\end{array}$} & \multicolumn{4}{|c|}{ Second-stage performance models } \\
\hline & $\begin{array}{c}\text { ROA for } \\
\text { Visits } \\
\text { Model } 1\end{array}$ & $\begin{array}{c}\text { ROA for } \\
\text { Non-visits } \\
\text { Model } 2\end{array}$ & $\begin{array}{c}\text { MTB for } \\
\text { Visits } \\
\text { Model } 3\end{array}$ & $\begin{array}{c}\text { MTB for } \\
\text { Non-visits } \\
\text { Model } 4\end{array}$ \\
\hline Intercept & $\begin{array}{c}31.61^{*} \\
(15.90)\end{array}$ & $\begin{array}{c}2.93 \\
(10.55)\end{array}$ & $\begin{array}{l}6.85^{* *} \\
(2.10)\end{array}$ & $\begin{array}{c}10.34^{* *} \\
(1.07)\end{array}$ \\
\hline 1. Firm size & $\begin{array}{r}-0.45 \\
(0.66)\end{array}$ & $\begin{array}{r}-0.20 \\
(0.51)\end{array}$ & $\begin{array}{c}-0.15+ \\
(0.08)\end{array}$ & $\begin{array}{c}-0.44^{* *} \\
(0.05)\end{array}$ \\
\hline 2. Current ratio & $\begin{array}{c}1.07^{* *} \\
(0.33)\end{array}$ & $\begin{array}{l}1.18^{* *} \\
(0.24)\end{array}$ & $\begin{array}{c}0.05 \\
(0.06)\end{array}$ & $\begin{array}{r}-0.01 \\
(0.03)\end{array}$ \\
\hline 3. Firm reputation & $\begin{array}{r}-0.44 \\
(1.12)\end{array}$ & $\begin{array}{c}0.54 \\
(0.54)\end{array}$ & $\begin{array}{r}-0.11 \\
(0.16)\end{array}$ & $\begin{array}{r}-0.15^{*} \\
(0.06)\end{array}$ \\
\hline 4. Technology resource & $\begin{array}{c}1.40 \\
(1.38)\end{array}$ & $\begin{array}{r}-0.48 \\
(0.86)\end{array}$ & $\begin{array}{c}0.06 \\
(0.23)\end{array}$ & $\begin{array}{c}0.08 \\
(0.07)\end{array}$ \\
\hline 5. Advertising intensity & $\begin{array}{c}1.12 \\
(4.68)\end{array}$ & $\begin{array}{c}2.07 \\
(3.33)\end{array}$ & $\begin{array}{c}1.29+ \\
(0.73)\end{array}$ & $\begin{array}{c}0.34 \\
(0.38)\end{array}$ \\
\hline 6. State ownership & $\begin{array}{r}-1.56 \\
(0.97)\end{array}$ & $\begin{array}{r}-0.14 \\
(0.55)\end{array}$ & $\begin{array}{c}-0.23+ \\
(0.12)\end{array}$ & $\begin{array}{c}0.08 \\
(0.05)\end{array}$ \\
\hline 7. Firm age & $\begin{array}{c}-0.48^{* *} \\
(0.08)\end{array}$ & $\begin{array}{c}-0.30^{* *} \\
(0.07)\end{array}$ & $\begin{array}{c}-0.06^{* *} \\
(0.02)\end{array}$ & $\begin{array}{r}-0.01 \\
(0.01)\end{array}$ \\
\hline 8. Market development & $\begin{array}{r}-0.59 \\
(0.91)\end{array}$ & $\begin{array}{l}2.05^{* *} \\
(0.65)\end{array}$ & $\begin{array}{r}-0.31^{*} \\
(0.14)\end{array}$ & $\begin{array}{c}0.12^{*} \\
(0.06)\end{array}$ \\
\hline 9. Group affiliation & $\begin{array}{c}-2.62^{* *} \\
(0.98)\end{array}$ & $\begin{array}{c}0.57 \\
(0.59)\end{array}$ & $\begin{array}{c}-0.27+ \\
(0.14)\end{array}$ & $\begin{array}{r}-0.02 \\
(0.06)\end{array}$ \\
\hline 10. Political connections & $\begin{array}{c}0.75 \\
(0.84)\end{array}$ & $\begin{array}{r}-0.08 \\
(0.50)\end{array}$ & $\begin{array}{c}0.01 \\
(0.11)\end{array}$ & $\begin{array}{r}-0.04 \\
(0.05)\end{array}$ \\
\hline 11. Mills ratio for visits & $\begin{array}{l}8.95^{* *} \\
(2.12)\end{array}$ & & $\begin{array}{c}1.10^{* *} \\
(0.36)\end{array}$ & \\
\hline 12. Mills ratio for non-visits & & $\begin{array}{c}12.53^{* *} \\
(2.35)\end{array}$ & & $\begin{array}{l}0.94^{* *} \\
(0.25)\end{array}$ \\
\hline Number of observations & 380 & 1185 & 380 & 1185 \\
\hline$R^{2}$ & 0.35 & 0.19 & 0.37 & 0.43 \\
\hline
\end{tabular}

Notes: ${ }^{\mathrm{a}} n=1565$. Bracketed numbers are standardized errors.

b $+\mathrm{p}<0.10 ;^{*} \mathrm{p}<0.05 ;{ }^{* *} \mathrm{p}<0.01$; two-tailed tests.

${ }^{\mathrm{c}}$ All five models include nine industry dummy variables and three year dummy variables not reported here.

for the endogeneity problem. Hypothesis 1 predicts that RGOV will be associated with better financial performance. Models 1 and 3 report the coefficient estimates for the effect of our covariates on ROA and MTB for companies that received government officials' visits. The coefficients of inverse Mills ratios were significant and positive in both regressions, indicating positive selection and implying that the ROA and MTB of these companies would have been worse if they had not received the visits. This finding provides strong support for Hypothesis 1.

Models 2 and 4 report the coefficient estimates for the effect of our covariates on ROA and MTB for companies that did not receive government officials' visits. The coefficients of inverse Mills ratios were also positive and significant, indicating that these companies would have had worse ROA and MTB had they been visited by 
government officials. A possible explanation is that this group of companies tended to be of lower quality than the companies that received government officials' visits. If they chose to lobby for the visits, the lobby costs could be higher than the benefits associated with such visits, indicating that 'dishonest signals do not pay' (Connelly, Certo, Ireland, \& Reutzel, 2011: 45).

Hypotheses 2 to 5 concern whether the effect of RGOV on financial performance is moderated by firm age, regional market development, group affiliation, and political connections. To test these moderating effect hypotheses, we followed Mayer and Nickerson's (2005) approach and compare the coefficients for firm age, regional market development, group affiliation, and political connections across subsamples. More specifically, we used the $\mathrm{z}$ test for the difference between two regression coefficients, in which

$$
\mathrm{Z}=\left(b_{1}-b_{2}\right) / \sqrt{\frac{V_{1}\left(S E b_{1}^{2}\right)+V_{2}\left(S E b_{2}^{2}\right)}{V_{1}+V_{2}}}
$$

where $b_{1}$ and $b_{2}$ are the regression coefficients for companies that received government officials' visits and for companies that did not, respectively; $V_{1}$ and $V_{2}$ are the degrees of freedom and $S E b_{1}^{2}$ and $S E b_{2}^{2}$ are the coefficient variances associated with the two subsamples. Table 5 presents the results of the $\mathrm{z}$ test. The coefficients of firm age, regional market development, and group affiliation were significantly different between the two subsamples for both ROA and MTB and the direction of the differences was as hypothesized, supporting Hypotheses 2, 3, and 4. The coefficients of political connections, on the other hand, were not significantly different from one another. Hence, Hypothesis 5 is not supported.

\section{Post-hoc Analyses}

We conducted some post-hoc analyses as follows. First, we used a treatment effect model as an alternative estimation method. A major difference between a switching regression and a treatment effect model is that the former does not restrict the independent variable coefficients in the second-stage performance equation to be the same for companies with and without government officials' visits. The results from treatment effect models are qualitatively the same as those shown in Tables 4 and 5. Second, in order to test whether the visits paid by officials of different levels of government have distinctive impacts on firm performance, we restricted our sample to firms that had received government officials' visits. We used hierarchical regression as the estimation method, and regressed firm financial performance on a dummy variable, receiving central government officials' visits. The results indicate that visits paid by central government officials and those paid by local government officials have similar effects on firm performance. Third, we examined the effect of the cumulative number of RGOV on firm performance. The results reveal that frequency of RGOV was positively and significantly associated with both ROA 
Table 5. Comparison of coefficients from switching regressions $\mathrm{s}^{\mathrm{ab}}$

\begin{tabular}{|c|c|c|c|c|c|c|}
\hline \multicolumn{7}{|c|}{ Dependent Variables } \\
\hline \multirow[b]{2}{*}{ Variables } & \multicolumn{3}{|c|}{$R O A$} & \multicolumn{3}{|c|}{$M T B$} \\
\hline & $\begin{array}{l}\text { Coefficients } \\
\text { for Visits }\end{array}$ & $\begin{array}{l}\text { Coefficients } \\
\text { for Non-visits }\end{array}$ & $\begin{array}{l}Z \text { test for the difference } \\
\text { between coefficients }\end{array}$ & $\begin{array}{l}\text { Coefficients } \\
\text { for Visits }\end{array}$ & $\begin{array}{l}\text { Coefficients } \\
\text { for Non-visits }\end{array}$ & $\begin{array}{l}Z \text { test for the difference } \\
\text { between coefficients }\end{array}$ \\
\hline Firm age & $\begin{array}{c}-0.48^{* *} \\
(0.08)\end{array}$ & $\begin{array}{c}-0.30^{* *} \\
(0.07)\end{array}$ & $-2.51^{*}$ & $\begin{array}{c}-0.06^{* *} \\
(0.02)\end{array}$ & $\begin{array}{r}-0.01 \\
(0.01)\end{array}$ & $-5.85^{* *}$ \\
\hline Market development & $\begin{array}{r}-0.59 \\
(0.91)\end{array}$ & $\begin{array}{l}2.05^{* *} \\
(0.65)\end{array}$ & $-3.64^{* *}$ & $\begin{array}{r}-0.31^{*} \\
(0.14)\end{array}$ & $\begin{array}{r}0.12^{*} \\
(0.06)\end{array}$ & $-4.88^{* *}$ \\
\hline Group affiliation & $\begin{array}{c}-2.62^{* *} \\
(0.98)\end{array}$ & $\begin{array}{c}0.57 \\
(0.59)\end{array}$ & $-4.50^{* *}$ & $\begin{array}{c}-0.27+ \\
(0.14)\end{array}$ & $\begin{array}{r}-0.02 \\
(0.06)\end{array}$ & $-2.99^{*}$ \\
\hline Political connections & $\begin{array}{l}0.75 \\
(0.84)\end{array}$ & $\begin{array}{r}-0.08 \\
(0.50)\end{array}$ & 1.37 & $\begin{array}{l}0.01 \\
(0.11)\end{array}$ & $\begin{array}{r}-0.04 \\
(0.05)\end{array}$ & 0.71 \\
\hline
\end{tabular}

Notes: ${ }^{\mathrm{a}} n=1565$. Bracketed numbers are standardized errors.

b $+p<0.10{ }^{*} p<0.05 ; * * p<0.01 ;$ two-tailed tests. 
and MTB. Finally, we reran our treatment effect models using two-year lag and three-year lag. In these models, RGOV was significantly related to both ROA and MTB. Hence the results indicate that the signaling effect of RGOV is not limited to a short period of time.

\section{DISGUSSION}

Do non-market actions truly contribute to firm performance? Drawing on insights from signaling theory, we develop a theoretical framework to examine how RGOV could play a role in influencing company financial performance in emerging economies. Overall, our results based on a sample of manufacturing companies in China confirm the value of signaling theory in explaining the relationship between RGOV and company financial performance.

We failed to find evidence for the moderating effect of political connections on the relationship between RGOV and performance. This might be due to the fact that it is costly to cultivate and maintain political connections (Sun et al., 2010; Sun et al., 2012). Since government agencies in emerging economies are still in control of strategic factor resources, there is intense competition among companies for preferential treatment. The result is that companies, including those with political connections, have to spend a great deal of effort on cultivating and maintaining their relationships with government agencies (Li \& Atuahene-Gima, 2001; Ma \& Parish, 2006). In addition, prior studies have suggested that the value of political connections is highly contingent on industry conditions (Li, Poppo, \& Zhou, 2008), and that changes in the market or non-market environment might turn political connections into a liability in emerging economies (Sun et al., 2012). Hence, it is likely that the benefits of political connections might be very limited for a large proportion of firms in our sample, and that RGOV still plays an important role for them in reducing transaction costs.

\section{Contributions and Implications}

This study makes several important theoretical contributions. First, it contributes to the research on non-market actions by integrating insights from signaling theory. Prior studies on non-market actions focused on actions taken by US firms such as lobbying and PAC contributions, and employed resource dependence theory as the main theoretical perspective to explain how non-market actions would have an impact on firm performance. Examining the effectiveness of RGOV, a popular form of non-market actions in emerging economies such as China, our study reveals that signaling theory could serve as a useful perspective delineating the mechanisms through which non-market actions would affect firm performance.

Second, we have elucidated the boundary conditions of the effectiveness of nonmarket actions. Based on a meta-analysis of the empirical studies on non-market actions, Lux et al. (2011: 243) noted that the effectiveness of non-market actions 'might 
be affected by other factors'. Yet little research to date has been done to empirically study these contingency factors. Our results indicate that RGOV has a greater effect when information asymmetry is more severe and when the signaling company lacks an alternative means of reducing transaction costs. These findings contribute to our knowledge of the boundary conditions affecting non-market actions.

Third, our findings contribute to signaling theory. In concluding their review of signaling theory, Connelly et al. (2011: 62) comment, 'The signaling environment on the whole is an under-researched aspect of signaling theory'. A major cause of the problem is that most of the studies were conducted in Western, developed economies. As shown by our study, which is probably the first of its kind, organizations can signal their unobserved quality through RGOV. Our study clearly indicates that in order to enrich the explanatory power of signaling theory, there is an urgent need for extending empirical research beyond Western, developed economies. In particular, emerging economies offer a fruitful research context because of the severe information asymmetry caused by their underdeveloped institutions.

Our study has managerial implications as well. From the perspective of companies doing business in emerging economies, our results suggest that it is beneficial for companies to lobby for government officials' visits. Once the visits are over, companies should publicize the visits, and even treat them as materials for impression management. This strategy is especially important for firms that are young and located in less developed regions. Multinational companies from Western, developed economies, in particular, might not be enthusiastic about RGOV, as these visits are of limited value in their home countries. However, they should note that institutional environments in the host and home countries can differ drastically, and they could benefit greatly from RGOV in an emerging economy.

Our findings also have policy implications. The Chinese government has been playing a prominent role in fostering economic growth (Fligstein \& Zhang, 2010). The effort that has been made by the Chinese government includes, but not limited to, building infrastructures, restructuring industries, attracting foreign direct investments, and encouraging entrepreneurship and innovation. Our results suggest that government officials might be able to promote economic development and improve social welfare by strategically selecting firms to visit. For example, government officials may visit high quality new ventures in economically backward regions. Doing so would provide support to these ventures and help them grow and contribute to regional development. Government officials in a polluted region may visit environmentally friendly firms so that these firms would become role models for other firms in the region to follow.

\section{Limitations}

A few limitations of the study should be acknowledged. The first one is about contextual generalization (Tsang \& Williams, 2012). Our sample consisted of 
listed Chinese manufacturing companies. The nature of the sample may limit the generalizability of the findings to other contexts. One context concerns the type of organizations. We limit the sample to listed companies because information on these firms is publicly available, but whether our results can be generalized to other types of firms remains a question. In particular, subsidiaries of multinational corporations in China could receive visits from not only Chinese government officials but also officials of their home countries. Hence, future studies may examine whether and how multinational corporations can benefit from these two distinct types of visits.

Another context is at the country level. RGOV may be particularly valuable in emerging economies, where the lack of market-supporting institutions has resulted in severe information asymmetries among exchange partners. In developed economies, on the other hand, exchange partners can rely on market institutions such as investment banks, auditors, lawyers, and consultants to collect reliable information. Accordingly RGOV plays a much less important role in reducing information asymmetry.

Further, although information asymmetries among exchange partners are much more severe in emerging economies, the generalizability of our results from China to other emerging economies needs further research. Indeed, emerging economies represent a highly heterogeneous group in terms of institutional environment (Tipton, 2009). That said, it does appear that RGOV also plays an important signaling role in some other emerging economies. For instance, the website of the Vietnamese company MyLan Group features the announcement of such a visit:

Deputy Prime Minister of Vietnam, Nguyen Sinh Hung, visited MyLan Group on Saturday, May 30, 2009. Deputy Prime Minister Nguyen Sinh Hung, toured the premises alongside MPM CEO, Dr. Nguyen Thanh My, to catch a glimpse of the company's day-to-day operations. Honoured by this personal visit, MPM extends many thanks to Deputy Prime Minister Nguyen Sinh Hung.

It seems that the importance of RGOV is positively associated with government intervention in business, but negatively associated with political (partisan) competition. Emerging economies differ in terms of the role played by the government in business (Tipton, 2009; Redding \& Witt, 2009). In some economies, such as South Africa, the central tenet of the government is to use price signals, property rights and transparent regulations to promote economic development, thereby reducing information asymmetries among the parties to a business transaction and weakening the signaling effect of RGOV. Moreover, government officials in such economies would refrain from intervening with business activities and using company visits as a means of showing political endorsement. Given these factors, RGOV is likely to have a weaker effect on firm performance.

Political (partisan) competition also weakens the value of RGOV because receiving visits by officials from one party may reduce the level of trust granted by the opposition parties (Choi, Jia, \& Lu, 2014; Zhu \& Chung, 2014). In emerging 
economies with intense political (partisan) competition, such as Thailand, RGOV not only signals a firm's underlying quality, but also indicates a firm's support toward and intimate relationship with the party to which the visiting official belongs. The value of RGOV is constrained to the extent that the opposition parties may punish the focal firm once they become the ruling parties (Zhu \& Chung, 2014). Future research in this area would benefit from an investigation of the effect of national institutional environment in terms of government intervention in business and political (partisan) competition on the value of RGOV.

Second, although we argue that RGOV influences financial performance by reducing transaction costs between a focal firm and its potential exchange partners, our methodology prevented us from directly examining the underlying mechanism linking RGOV and firm performance. It is possible that RGOV might serve as one kind of activating signals, which 'indicate a characteristic that separate the signaler from competitors and are also essential to activating the quality in the signaler' (Connelly et al., 2011: 60). RGOV might provide the focal firm with opportunities to build connections with more government officials, which in turn are beneficial to firm performance. Furthermore, it might be possible that firms that have received government officials' visits subsequently manipulate earnings in order to fulfill the optimistic outlooks they portrayed to the government officials. Nevertheless, these two alternative mechanisms cannot explain our empirical results concerning the contingency effects (as proposed by Hypotheses 2 to 5).

Finally, although our field study suggests that firms in China solicit visits from government officials, we cannot rule out the possibility that government officials initiate some of the visits in order to show their commitment toward economic development and social welfare. However, if the firms that receive such visits heavily advertise the visits afterwards on their websites, they can be said to engage in nonmarket actions, similar to those that solicit the visits. Since the current study relied on companies' websites as the source of data, all the firms coded as having RGOV did advertise the visits. In the language of signaling theory, these firms tend to have high underlying quality, and thus the signaling costs for them are much lower than those for low-quality firms, involving mainly the cost of hosting the visits and publicizing costs. Nevertheless, future research may include in-depth case studies to examine the differences between visits initiated by firms and those initiated by government officials.

\section{CONGLUSION}

This study examined the effect of one form of non-market actions, RGOV, on firm performance in China. The results indicate that RGOV improves company financial performance, and that the link between RGOV and performance depends on two contingencies: (1) the severity of information asymmetry between companies and their potential exchange partners, and (2) the availability of alternative means 
of reducing transaction costs. The findings contribute to our understanding of the roles of non-market actions in emerging economies.

\section{NOTES}

We are grateful to Klaus Meyer (deputy editor-in-chief), and three anonymous reviewers for their constructive and detailed comments on previous versions of our article. We also thank the support provided by the National Natural Science Foundation of China (Grant Numbers 7 1202095, 71572198, 71232009, 71373167, and 71003108) and the Guangdong Planning Office of Philosophy and Social Science Program (Grant Number GD14XGL13).

\section{REFERENGES}

Aldrich, H. E., \& Fiol, C. M. 1994. Fools rush in? The institutional context of industry creation. Academy of Management Revieze, 19(4): 645-670.

Baron, D. P. 1995. Integrated strategy: Market and nonmarket components. California Management Review, 37(2): 47-65.

Burris, V. 2001. The two faces of capital: Corporations and individual capitalists as political actors. American Sociological Revieze, 66(3): 361-381.

Caldeira, G. A., Jojnacki, M., \& Wright, J. R. 2000. The lobbying activities of organized interests in Federal judicial nominations. Journal of Politics, 62(1): 51-69.

Certo, S. T. 2003. Influencing initial public offering investors with prestige: Signaling with board characteristics. Academy of Management Review, 28(3): 432-446.

Chan, G. M., Makino, S., \& Isobe, T. 2010. Does subnational region matter? Foreign affiliate performance in the US and China. Strategic Management Journal, 31(11): 1226-1243.

Chen, G., Hambrick, D. C., \& Pollock, T. G. 2008. Puttin' on the Ritz: Pre-IPO enlistment of prestigious affiliates as deadline-induced remediation. Academy of Management ofJournal, 31(5): 954-975.

Choi, S. J., Jia, N., \& Lu, J. 2014. The Structure of political institutions and effectiveness of corporate political lobbying. Organization Science, 26(1): 158-179.

Cohen, B. D., \& Dean, T. J. 2005. Information asymmetry and investor valuation of IPOs: Top management team legitimacy as a capital market signal. Strategic Management Journal, 26(7): 683-690.

Connelly, B. L., Certo, S. T., Ireland, R. D., \& Reutzel, C. R. 2011. Signaling theory: A review and assessment, Journal of Management, 37(1): 39-67.

De Crespigny, R. 1981. Inspection and surveillance officials under the two Han dynasties. In D. Eikemeier \& H. Franke (Eds.), State and Law in East Asia: 40-79. Wiesbaden: Otto Harrassowitz.

Dyer, J. H., \& Chu, W. 2003. The role of trustworthiness in reducing transaction costs and improving performance: Empirical evidence from the United States, Japan, and Korea. Organization Science, 14(1): 57-68.

Fan, G., \& Wang, X. L. 2009. NERI Index of Marketization of China's provinces. Beijing: Economic Science Press (in Chinese).

Fan, J. P., Wong, T. J., \& Zhang, T. 2007. Politically connected CEOs, corporate governance, and post-IPO performance of China's newly partially privatized firms. Journal of Financial Economics, 84(2): 330-357.

Fligstein, N., \& Zhang, J. 2011. A new agenda for research on the trajectory of Chinese capitalism. Management and Organization Review, 7(1): 39-62.

Glaser, B., \& Strauss, A. 1967. The discovery of grounded theory: Strategies for qualitative research. London: Wiedenfeld and Nicholson.

Hadani, M., \& Schuler, D. A. 2013. In search of El Dorado: The elusive financial returns on corporate political investments. Strategic Management Journal, 34(2): 165-181.

Hamilton, B. H., \& Nickerson, J. A. 2003. Correcting for endogeneity in strategic management research. Strategic Organization, 1(1): 51-78.

Hansen, W., \& Mitchell, N. 2001. Globalization or nation capitalism: Large firms, national strategies and political activities. Business and Politics, 3(1): 5-19. 
Hasen, I., Kobeissi, N., \& Wang, H. 2011. Global equity offerings, corporate valuation, and subsequent international diversification. Strategic Management Journal, 32(7): 787-796.

He, Y., \& Tian, Z. 2008. Government-oriented corporate public relation strategies in transitional China. Management and Organizational Revieze, 4(3): 367-391.

He, Y., Tian, Z., \& Chen, Y. 2007. Performance implications of nonmarket strategy in China. Asia Pacific Journal of Management, 24(2): 151-169.

Higgins, M. C., \& Gulati, R. 2003. Getting off to a good start: The effects of upper echelon affiliations on underwriter prestige. Organization Science, 14(3): 244-263.

Higgins, M. C., \& Gulati, R. 2006. Stacking the deck: The effects of top management backgrounds on investor decisions. Strategic Management Journal, 27(1): 1-25.

Hillman, A. J., Zardkoohi, A., \& Bierman, L., 1999. Corporate political strategies and firm performance: Indications of firm-specific benefits from personal service in the US government. Strategic Management Journal, 20(1): 67-81.

Hillman, A. J., Keim, G. D., \& Schuler, D. 2004. Corporate political activity: A review and research agenda. Journal of Management, 30(6): 837-857.

Hucker, C. O. 1951. The traditional Chinese censorate and the new Peking regime. American Political Science Review, 45(4): 1041-1057.

Iyengar, R. J., \& Zampelli, E. M. 2009. Self-selection, endogeneity, and the relationship between CEO duality and firm performance. Strategic Management Journal, 30(10): 1092-1112.

Jia, N. 2014. Are collective political actions and private political actions substitutes or complements? Empirical evidence from China's private sector. Strategic Management Journal, 35(2): 292-315.

Khanna, T., \& Palepu, K. 1997. Why focused strategies may be wrong for emerging markets. Harvard Business Review, 75(4): 41-51.

Khanna, T., \& Palepu, K. 2000. Is group affiliation profitable in emerging markets? An analysis of diversified Indian business groups. Journal of Finance, 55(2): 867-891.

King, A. M. 1999. What is the value of your website? Strategic Finance, 80(9): 48-51.

Leiblein, M. J., Reuer, J. J., \& Dalsace, F. 2002. Do make or buy decisions matter? The influence of organizational governance on technological performance. Strategic Management Journal, 23(9): 817-833.

Li, H., \& Atuahene-Gima, K. 2001. Product innovation strategy and the performance of new technology ventures in China. Academy of Management Journal, 44(6): 1123-1134.

Li, H., Meng, L., \& Zhang, J. 2006. Why do entrepreneurs enter politics? Evidence from China. Economic Inquiry, 44(3): 559-578.

Li, H., \& Zhang, Y. 2007. The role of managers political networking and functional experience in new venture performance: Evidence from China's transition economy. Strategic Management Journal, 28(8): 791-804.

Li, J.J., Poppo, L., \& Zhou, K. Z. 2008. Do managerial ties in China always produce value? Competition, uncertainty, and domestic vs. foreign firms. Strategic Management Journal, 29(4), 383-400.

Li, J., \& Qian, C. 2013. Principal-principal conflicts under weak institutions: A study of corporate takeovers in China. Strategic Management Journal, 34(4): 498-508.

Li, J., Chen, D., \& Shapiro, D. M. 2010. Product innovations in emerging economies: The role of foreign knowledge access channels and internal efforts in Chinese firms. Management and Organization Revieze, 6(2): 243-266.

Lu, J. W., \& Ma, X. 2008. The contingent value of local partners business group affiliations. Academy of Management Journal, 51 (2): 295-314.

Luo, X. R., \& Chung, C. N. 2013. Filling or abusing the institutional void? Ownership and management control of public family businesses in an emerging market. Organization Science, 24(2): 591-613.

Luo, Y. 2003. Industrial dynamics and managerial networking in an emerging market: The case of China. Strategic Management Journal, 24(13): 1315-1327.

Luo, Y. 2006. Political behavior, social responsibility, and perceived corruption: A structuration perspective. Journal of International Business Studies, 37(6): 747-766.

Lux, S., Crook, T. R., \& Woehr, D. J. 2011. Mixing business with politics: A meta-analysis of the antecedents and outcomes of corporate political activity. Journal of Management, 37(1): 223-247.

Ma, D., \& Parish, W. L. 2006. Tocquevillian moments: Charitable contributions by Chinese private entrepreneurs. Social Forces, 85(2): 943-964. 
Ma, X., Yao, X., \& Xi, Y. 2006. Business group affiliation and firm performance in a transition economy: A focus on ownership voids. Asia Pacific Journal of Management, 23(4): 467483.

Marsh, S. J. 1998. Creating barriers for foreign competitors: A study of the impact of anti-dumping actions on the performance of US firms. Strategic Management Journal, 19(1): 25-37.

Masten, S. 1993. Transaction costs, mistakes, and performance: Assessing the importance of governance. Managerial and Decision Economics, 14(2): 119-129.

Mayer, K. J., \& Nickerson, J. A. 2005. Antecedents and performance implications of contracting for knowledge workers: Evidence from information technology services. Organization Science, 16(3): 225-242.

Meyer, K. E. 2001. Institutions, transaction costs, and entry mode choice in Eastern Europe.Journal of International Business Studies, 32(2): 357-367.

Meyer, K. E., Estrin, S., Bhaumik, S. K., \& Peng, M. W. 2009. Institutions, resources, and entry strategies in emerging economies. Strategic Management Journal, 30(1): 61-80.

Meyer, K. E., \& Nguyen, H. V. 2005. Foreign investment strategies and subnational institutions in emerging markets: Evidence from Vietnam. Journal of Management Studies, 42(1): 63-93.

Meyer, K. E., \& Peng, M. W. 2005. Probing theoretically into Central and Eastern Europe: Transactions, resources, and institutions.Journal of International Business Studies, 36(6): 600-621.

Oliver, C., \& Holzinger, I. 2008. The effectiveness of strategic political management: A dynamic capabilities framework. Academy of Management Revieze, 33(2): 496-520.

Ozmel, U., Reuer, J., \& Gulati, R. 2012. Signals across multiple networks: How venture capital and alliance networks affect interorganizational collaboration. Academy of Management Journal, 56(3): 852-866.

Peng, M. W., \& Luo, Y. 2000. Managerial ties and firm performance in a transition economy: The nature of a micro-macro link. Academy of Management Journal, 43(3): 486-501.

Poppo, L., \& Zenger, T. 1998. Testing alternative theories of the firm: Transaction cost, knowledgebased, and measurement explanations for make-or-buy decisions in information services. Strategic Management Journal, 19(9): 853-877.

Qian, Y., \& Weingast, B. R. 1997. Federalism as a commitment to preserving market incentives. Journal of Economic Perspectives, 11(4): 83-92.

Rangan, S. 2000. The problem of search and deliberation in economic action: When social networks really matter. Academy of Management Revieze, 25(4): 813-828.

Redding, G., \& Witt, M. A. 2009. China's business system and its future trajectory. Asia Pacific Journal of Management, 26(3): 381-399.

Roberts, P. W., \& Dowling, G. R. 2002. Corporate reputation and sustained superior financial performance. Strategic Management Journal, 23(12): 1077-1093.

Shaffer, B. 1995. Firm-level responses to government regulation: Theoretical and research approaches. Journal of Management, 21(3): 495-514.

Shaffer, B., Quasney, T. J., \& Grimm, C. M. 2000. Firm level performance implications of nonmarket actions. Business and Society, 39(2): 126-143.

Shaver, J. M. 1998. Accounting for endogeneity when assessing strategy performance: Does entry mode choice after FDI survival? Management Science, 44(4): 571-585.

Song, M., Droge, C., Hanvanich, S., \& Calantone, R. 2005. Marketing and technology resource complementarity: An analysis of their interaction effect in two environmental contexts. Strategic Management Journal, 26(3): 259-276.

Spence, M. 1973. Job market signaling. Quarterly Journal of Economics, 87(3): 355-374.

Stuart, T. E. 1998. Network positions and propensities to collaborate: An investigation of strategic alliance formation in a high-technology industry. Administrative Science Quarterly, 43(3): $668-698$.

Stuart, T. E., Hoang, H., \& Hybels, R. C. 1999. Interorganizational endorsements and the performance of entrepreneurial ventures. Administrative Science Quarterly, 44(2): 315 349.

Suchman, M. C. 1995. Managing legitimacy: Strategic and institutional approaches. Academy of Management Revieze, 20(3): 571-610.

Sun, P., Mellahi, K., \& Thun, E. 2010. The dynamic value of MNE political embeddedness: The case of the Chinese automobile industry.Journal of International Business Studies, 41(7): $1161-1182$ 
Sun, P., Mellahi, K., \& Wright, M. 2012. The contingent value of corporate political ties. Academy of Management Perspectives, 26(3): 68-82.

Tan, J., \& Peng, M. W. 2003.Organizational slack and firm performance during economic transitions: Two studies from an emerging economy. Strategic Management Journal, 24(13): 1249 1263.

Tipton, F. B. 2009. Southeast Asian capitalism: History, institutions, states, and firms. Asia Pacific Journal of Management, 26(3): 401-434.

Tsang, E. W. K., \& Williams,J. N. 2012. Generalization and induction: Misconceptions, clarifications, and a classification of induction. MIS Quarterly, 36(3): 729-748.

Walker, R. L. 1947. The control system of the Chinese government. Far Eastern Quarterly, 7(1): $2-21$.

Wang, H., \& Qian, C. 2011. Corporate philanthropy and corporate financial performance: The roles of stakeholder response and political access. Academy of Management Journal, 54(6): $1159-1181$.

Williamson, O.E. 1991. Comparative economic organization: The analysis of discrete structural alternatives. Administrative Science Quarterly, 36(2): 269-296.

Zhang, J., \& Luo, X. R. 2013. Dared to care: Organizational vulnerability, institutional logics, and MNCs' social responsiveness in emerging markets. Organization Science, 24(6): 1742-1764.

Zhu, H., \& Chung, C. N. 2014. Portfolios of political ties and business group strategy in emerging economies: Evidence from Taiwan. Administrative Science Quarterly, 59(4): 599-638.

Zott, C., \& Huy, Q. N. 2007. How entrepreneurs use symbolic management to acquire resources. Administrative Science Quarterly, 52(1): 70-105.

Weiwen Li (allenliweiwen@gmail.com) is an associate professor at Sun Yat-sen Business School, Sun Yat-sen University. His research interests include strategic leadership, family business, and corporate governance. He has published papers in Journal of International Business Studies, Management and Organization Review, and Asia Pacific Journal of Management.

Eric W. K. Tsang (ewktsang@utdallas.edu) is the Dallas World Salute Distinguished professor of Global Strategy at the Naveen Jindal School of Management, University of Texas at Dallas. He received his $\mathrm{PhD}$ from the University of Cambridge. His main research interests include organizational learning, strategic alliances, initial public offerings, corporate social responsibility, and philosophical analysis of methodological issues.

Danglun Luo (luodl@mail.sysu.edu.cn) is an associate professor at Lingnan (University) College, Sun Yat-sen University. His research interests include corporate finance and corporate governance. He has published papers in Regional Science and Urban Economics, and Emerging Markets Finance and Trade.

Qianwei Ying (yingqianwei@126.com) is an associate professor at Business School, Sichuan University. His research interests include corporate finance, corporate governance, and transitional economy. He has published papers in Urban Studies, Fournal of Contemporary China, and Emerging Markets Finance and Trade.

Manuscript received: June 27, 2014

Final version accepted: July 27, 2015 (number of revisions - 3)

Accepted by: Deputy Editor-in-Chief Klaus Meyer 